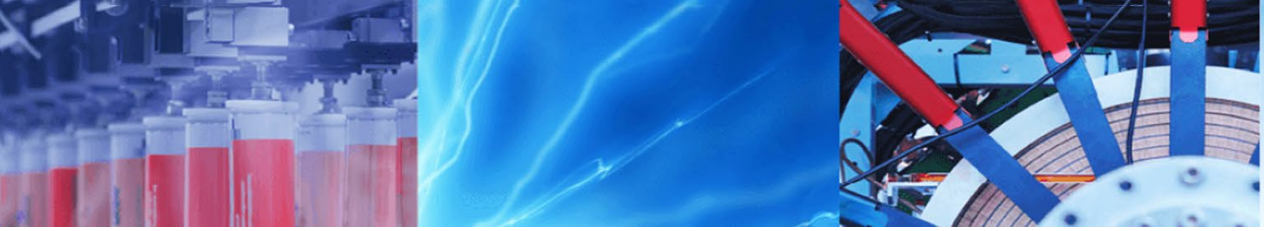

Research Article

\title{
Morphometric and physicochemical characteristics of carob pods in three geographical regions of Morocco
}

\author{
Fatiha Fadel ${ }^{1,2} \cdot$ Khadija El Mehrach $^{2} \cdot$ Bouchra Chebli $^{1} \cdot$ Fadma Fahmi $^{2} \cdot$ Mohamed El Hafa $^{3} \cdot$ Oukacha Amri $^{2}$. \\ Mohamed Ait Bihi ${ }^{2} \cdot$ Abdelhakim Hatimi $^{2}$-Saida Tahrouch ${ }^{2}$ (i)
}

Received: 8 July 2020 / Accepted: 25 November 2020 / Published online: 9 December 2020

(c) Springer Nature Switzerland AG 2020

\begin{abstract}
In three different regions of Morocco, i.e., the center, north and southwest, pulps and seeds from eight carob trees, Ceratonia siliqua L., were compared in order to characterize and promote the carob tree and its subspecies as new potential development for rural development and soil conservation. Twelve different morphometric parameters of the trees were investigated. The results showed significant differences between the pods of the three regions for most parameters $(p=0.05)$. The pods and the seeds of the north are thicker, longer and wider for apical, median and basal width and hereby a mass of seeds per pod which are important. The differences between the trees in the three regions showed a clear separation of the northern region of Morocco from the two other regions. Phytochemical study for flavonoids and saponins in the pulps of the trees showed a significant difference between the three regions. However, the difference for total phenols was not significant. The carob pulp of the north was rich in fat and total sugars, while the carob of the center is rich in total nitrogen and total protein. For seeds, the difference was not significant between the three regions in water content, fatty acids and total flavonoids. However, the carob seeds of the southwest Morocco have the highest content of total nitrogen, total protein, total sugars and saponins.
\end{abstract}

Keywords Ceratonia siliqua $\cdot$ Pods $\cdot$ Seeds $\cdot$ Morphometric $\cdot$ Physicochemical analysis $\cdot$ Pulp

\section{Introduction}

The climate in Morocco is both Mediterranean and Atlantic with a hot, dry season associated with cold and rainy and wet periods. The ecogeographic and climatic factors play a significant role in the type of vegetation [1]. Moreover, erosion and desertification cause an annual loss of about 31,000 hectares of vegetation. For the rural populations, forest products are needed, and therefore substantial efforts are devoted to reforestation (10 to 15,000 hectares/ year). However, according the Ministry of Forestry, reforestation failures are very common. Using species known for their adaptation strategies to climate change could improve the success rate of reforestation operations. Populations of carob tree are widely distributed in arid and subarid area in Morocco (in the Rif and Atlas Mountains and in the valleys of southwestern Anti-Atlas); it plays a great role in the biodiversity of the forest's ecosystem. Several plants of carob tree from Mediterranean origin have been characterized [2-4]. The carob trees have a great potential for reforestation [5].

To identify the most valuable and suitable subspecies of the carob trees (Ceratonia siliqua L.) for plantation, the morphometric characterization and determination of chemical composition of carob pod from Chefchaouen (region in the north of Morocco) were studied.

$\triangle$ Saida Tahrouch, tahrouch@hotmail.com | ${ }^{1}$ Ecole Nationale des Sciences Appliquées, Université Ibn Zohr, BP 1136/S, Agadir, Morocco. ${ }^{2}$ Laboratoire de Biotechnologies Végétales, faculté des Sciences, Université lbn Zohr, BP 8106, Agadir, Morocco. ${ }^{3}$ Département de Biologie, Faculté Des Sciences, Université Ibn Zohr, BP 8106, Agadir, Morocco. 
Furthermore, the chemical composition of carob pods was investigated. With respect to the scientific literature, no comparative morphometric characterization associated with physicochemical studies has been performed before on these areas. In the present study, at three different locations in Morocco, an evaluation of the effect of environmental conditions on the morphometric and the physicochemical properties of pulps and seeds of the carob trees has been studied.

\section{Materials and methods}

\subsection{Plant material}

From three regions of Morocco, samples of Ceratonia siliqua L. were harvested:

- In the north: in two localities: Al Hoceima and Chefchaouen.

- The center: Azilal, Demnate and Ouzoud.

- In the southwest: The samples were harvested from Izouika, Reggada and Imouzzer Ida Ou Tanane.

A geographic database (latitude, longitude, altitude and precipitations) was recorded for each location using a global positioning system (Table 1). The locations represent different soil conditions and a variety of climatic conditions corresponding to different eco-geographical situations. Randomly, ripe carob pods collections were carried out from 85 trees: 20 in the north, 30 in the center and 35 in the southwest. The samples were packed, labeled and brought to the laboratory for analyses and data collection.

\subsection{Morphometric analyses}

The morphometric analyses were performed using 30 pods and 30 seeds for each sampled tree from the three localities. Morphometric analysis was carried out on 30 cloves per tree based on the following parameters: pod length (LG), apical width (LGa), median width (LGm) and basal (LGb), pod thickness (EG), number seeds per pod $(\mathrm{NgG})$, pod mass $(\mathrm{PG})$, seed mass per pod $(\mathrm{PgG})$, mass of the pulp (PP), degree of curvature (C) and length of peduncle (LP). Thirty seeds were chosen randomly, after crushing the pods. The morphometrics measures of the seed were carried out based on the following parameters: length (Log), width (lg) and thickness of the seed (Eg).

\subsection{Physicochemical analyses}

The pods and seeds were used for biometric study: determination of the moisture content, the crude ash and the physicochemical analyses: total nitrogen, total protein, crude fat, flavonoids and total saponins. Total sugar and total phenols contents were determined according to Dubois et al. [6] and Dai et al. [7] methods, respectively.

\subsubsection{Humidity}

Five grams ( $\mathrm{g}$ ) of powder of each carob sample was placed in a stove oven preheated at $103^{\circ} \mathrm{C}$. After $4 \mathrm{~h}$ of drying, the samples were covered and cooled in the desiccators for $40 \mathrm{~min}$. Moisture content, as a percentage, was calculated for each sample according to the following formula:

$H=(E-m) \cdot \frac{100}{E}$

where $E=$ mass in grams of the test sample, and $m=$ mass in grams, of the dry test.

\subsubsection{Crude ash}

The determination of crude ash was performed following the instructions of the French standardization system (NF V18-101) [8]. The crude ash content (CA), as a percentage, was calculated using the following formula:

Table 1 Geographical and meteorological conditions in harvesting areas of carob pods

\begin{tabular}{llllllll}
\hline & Ecoregions & Geographic region & Latitude $N$ & Longitude w & Altitude $\mathrm{m}$ & Rainfall mm/year & Temperature ${ }^{\circ} \mathrm{C}$ \\
\hline \multirow{2}{*}{ North } & El Hoceima & Rif & $35^{\circ} 11^{\prime}$ & $3^{\circ} 57^{\prime}$ & $50-250$ & 327 & 22 \\
& Chefchaouen & Rif & $35^{\circ} 12^{\prime}$ & $5^{\circ} 16^{\prime}$ & $350-550$ & 700 & 17 \\
\multirow{3}{*}{ Center } & Azilal & High atlas & $31^{\circ} 58^{\prime} 01^{\prime \prime}$ & $6^{\circ} 34^{\prime} 10^{\prime \prime}$ & 1351 & 400 to 600 & 33 \\
& Demnate & Middle atlas & $31^{\circ} 43^{\prime} 52$ & $7^{\circ} 02^{\prime} 10^{\prime \prime}$ & 968 & 300 to 500 & 33 \\
& Ouzoud & Middle atlas & $32^{\circ} 1^{\prime} 48$ & $6^{\circ} 46^{\prime} 48$ & 553 & 22.9 \\
\multirow{5}{*}{ Southwest } & Imouzzer Ida Ou Tanane & Ouest of High Atlas & $30^{\circ} 40^{\prime} 12$ & $9^{\circ} 28^{\prime} 48$ & 1160 & 120 to 400 & 18.3 \\
& Izouika & Anti atlas & $29^{\circ} 54^{\prime} 36^{\prime \prime}$ & $9^{\circ} 33^{\prime} 0^{\prime \prime}$ & 123 & 150 to 200 & 19.2 \\
& Reggada & Anti atlas & $29^{\circ} 34^{\prime} 48$ & $9^{\circ} 41^{\prime} 60$ & 403 & & 22 \\
\hline
\end{tabular}


I. $\quad \mathrm{CB}=(m 2-m 0) \cdot \frac{100}{m 1-m 0}$

where $m_{0}$ is the mass, in grams, of the empty crucible, $m_{1}$ is the mass, in grams, of the crucible containing the sample, and $m_{2}$ is the mass, in grams, of the crucible and crude ash.

\subsubsection{Total nitrogen and total protein}

Mineralization of $1 \mathrm{~g}$ of finely ground sample was performed by a digester 12 posts Selecta TC Type K in the presence of concentrated sulfuric acid and $10 \mathrm{~g}$ of catalyst ( $\mathrm{CuSO}_{4}, \mathrm{~K}_{2} \mathrm{SO}_{4}$ and $\mathrm{Se}$ ). The heating was performed gently until the mass has carbonized and the foam disappears and then louder until $410^{\circ} \mathrm{C}$ for $3 \mathrm{~h}$. The distillation was carried out by a nitrogen-type distiller VELP UDK 127 and titration $1 \mathrm{~N}$ sulfuric acid. Proteins were calculated from the total Kjeldahl nitrogen using a conversion factor of 6.25 proteins per gram of sample.

\subsubsection{Crude fats}

A $5 \mathrm{~g}$ of each sample of carob powder was placed in the extractor type SER 148 VELP SCIENTIFICA RS-232. The crud fats were isolated using petroleum ether. The apparatus was heated at $115^{\circ} \mathrm{C}$ in three steps: immersion for $30 \mathrm{~min}$, washing for $60 \mathrm{~min}$ and finally recovery for $45 \mathrm{~min}$. Then, the residue was dried in a stove oven with vacuum maintained at a temperature of $105^{\circ} \mathrm{C}$ and then cooled in desiccators and weighed.

\subsubsection{Total flavonoids}

The assays were performed in UV-visible spectrophotometer Vectra 8453 diode array type HP. One gram of powdered sample was mixed with $100 \mathrm{ml}$ of $80 \%$ methanol. After stirring and sonication, $2 \mathrm{ml}$ of the extract was mixed with $100 \mathrm{ml}$ of Neu's reagent. The absorption was determined at $404 \mathrm{~nm}$ and compared to the standard quercetol $(0.05 \mathrm{mg} / \mathrm{ml})$. The standard was treated with the same amount of reagent [9]. The percentage of total flavonoids was calculated as equivalent quercetol according to the following formula [10]:

$F=(0,05 \times$ Aext $/$ Aq. $) \times 100 /$ Cext $(\%)$

where Aext is the absorption of the extract; Aq is the absorption of the quercetol; and Cext is the concentration of the plant extract which is $10 \mathrm{mg} / \mathrm{ml}$.

The percentages of total flavonoids are converted and then calculated as $\mathrm{mg} / \mathrm{g}$ of dry matter.

\subsubsection{Saponins}

The foam index was used to determine the presence of saponins. For this, $1 \mathrm{~g}$ of each sample powder was added to $100 \mathrm{ml}$ of distilled water and boiled for $30 \mathrm{~min}$. After cooling and filtration using Whatman paper, the volume was adjusted to $100 \mathrm{ml}$ with distilled water. Ten test tubes containing 1 to $10 \mathrm{ml}$ of decoction were prepared and adjusted to $10 \mathrm{ml}$ with distilled water. Following a violent horizontal shaking, the tubes were allowed to stand for $15 \mathrm{~min}$. Then, the height of the foam remaining in each tube was measured in $\mathrm{cm}$ and the foam index $(I)$ was calculated according to the following formula:

$I=$ Foam height in the 9th tube $*(10 / 0,09)$.

The presence of saponins in the plant is confirmed if the foam index is greater than 100 .

\subsubsection{Total sugars}

An amount of $1 \mathrm{~g}$ of powdered sample was dispersed in $10 \mathrm{ml}$ of dimethyl sulfoxide (DMSO) at $25 \%$ in water $(\mathrm{v} / \mathrm{v})$. After $15 \mathrm{~min}$ of incubation in a boiling water bath, a $0.1 \mathrm{ml}$ of the mixture was diluted with $9.9 \mathrm{ml}$ of water. The amount of $0.5 \mathrm{ml}$ of the extract was added to $0.5 \mathrm{ml}$

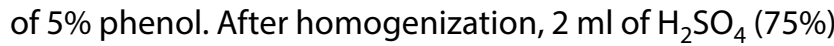
was added. This mixture was incubated in a boiling water bath for $15 \mathrm{~min}$ and then allowed to cool for $15 \mathrm{~min}$ in the dark. The optical density (OD) was determined at $292 \mathrm{~nm}$.

\subsubsection{Total phenols}

A volume of $25 \mu$ l of each extract was mixed with $110 \mu \mathrm{l}$ of Folin-Ciocalteu reagent [11] and homogenized, and then the mixture was left to stand for $3 \mathrm{~min}$. After, $200 \mu \mathrm{l}$ of sodium carbonate (20\%) was added followed by $1.9 \mathrm{ml}$ of distilled water. The mixture was placed for $30 \mathrm{~min}$ at $60^{\circ} \mathrm{C}$, and the optical density was read at $750 \mathrm{~nm}$. The calibration curve used to calculate the total concentration of phenolic compounds was determined with caffeic acid.

\subsection{Statistical analysis}

The results of the morphometric and the physicochemical study were evaluated using EXCEL and STATISTICA 6. The statistical analyses followed were principal component analysis (PCA) and factorial discriminant analysis (FDA). FDA was made based on the sugar content, protein, fat, total flavonoids, total phenolic and saponins. 


\section{Results and discussion}

\subsection{Morphometric variability}

Statistical analysis of the results from the morphometric analyses of the carob trees between the three regions of the carob trees showed significant differences for the following ten parameters: mass, length and thickness of the pod, apical, middle and basal width of fruit, number of seeds per pod, seed mass per pod and seed length and width (Table 2). Moreover, the carob pod in northern Morocco is heavier, longer, wider and thicker (Table 2). The seeds of the trees from this region were longer and wider than those in the south and central Morocco. The fruits of northern Morocco had a longer stalk $(13.75 \mathrm{~mm})$ and a heavier pulp $(9.12 \mathrm{~g})$ compared to other studied regions. A significant difference was found for the trees between the north and south for all studied morphometric parameters except for the degree of curvature. The difference between the south and the center is not significant for stem length, the mass of the pulp and seed thickness (Table 2). This difference between regions is confirmed by a dendrogram that shows a clear separation of the northern region from the two other regions (Fig. 1). These results are in agreement with those obtained by Makrem et al. [12] in Tunisia and by Barracosa et al. [2] in Portugal. The results concerning the seeds of the northern region of Morocco are similar to those reported in Fez (Morocco) by Elfazazi et al. [13]. On the other hand, cultivation practices of carob seem to improve the mass of the pod, the stem length, the mass of the pulp, the length of the seed and the apical and basal width of the pod. Rainfall and temperature are the most important climatic parameters influencing the carob tree distribution [14]. Rainfall in northern Morocco seems to favor the mass, length, thickness and width of the pod and length of the stalk. These results were confirmed by those found by Barracosa et al. [2] who reported that the Moroccan ecoregions north pods were longer, wider, heavier and thicker. If rainfall increases, the mass of the pulp, the length, the width and the thickness of the seeds increase, inducing the mass of seeds per pod.

With respect to pharmacological uses, the pulp is known to be used in the prevention and treatment of a wide variety of diseases, including diabetes, hyperlipidemia, irritable bowel syndrome and colon cancer [15].

\subsection{Physicochemical analyses}

The results of physicochemical analyses presented a significant difference for both total flavonoids and saponins between the carob pulp from the southern, the central

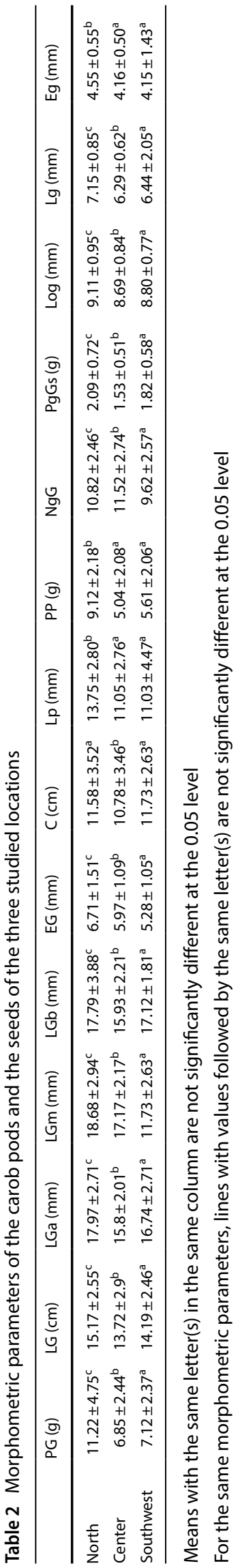


and the northern Morocco. However, the pulps from the south have the highest percentages of these compounds (Table 3). The pulps of the trees from the three studied regions showed no significant difference in total phenols. The richness of flavonoids and saponins in pulps from trees of southwest may be due to environmental conditions. In fact, the carob trees in the southwestern regions, with high temperatures and less precipitations, probably reacted to this by increasing the pool of flavonoids [16]. Ruiz et al. [17] have reported that changes in the content of saponins depend mainly on the variety, origin and the region wherein the plant is growing. The high flavonoids content in carob pulp may increase the commercial value of the carob tree. It is well known that flavonoids have multiple biological activities: anti-carcinogenic, anti-inflammatory and anti-viral $[18,19]$. They are also excellent antioxidants and free radical scavengers $[20,21]$.
Regarding the content of flavonoids in seeds, no significant difference was observed between the three regions despite the involvement of environmental conditions and genetic factors in their production rate [22]. However, the seeds from the trees of the north have a rate of total phenols higher than those from the trees in the center and southwest of Morocco. This may be due to the carob variety as confirmed by Nassourou et al. [22]. They showed that the content of phenolic compounds in plants was affected by germination, maturity, variety, processing and storage of seeds.

For the other studied parameters such as total nitrogen, total protein, total sugars and total phenols, the differences were not significant between the pulps of the three studied regions (Table 3). Also, no significant differences were observed between the carob seeds of the three regions for water and fat contents (Table 4). Thus, the physicochemical composition of the carob pulp from trees in north, center and southwest of Morocco differs only for the content of
Fig. 1 Dendrogram of morphometric traits of pods and seeds of the three studied carob locations

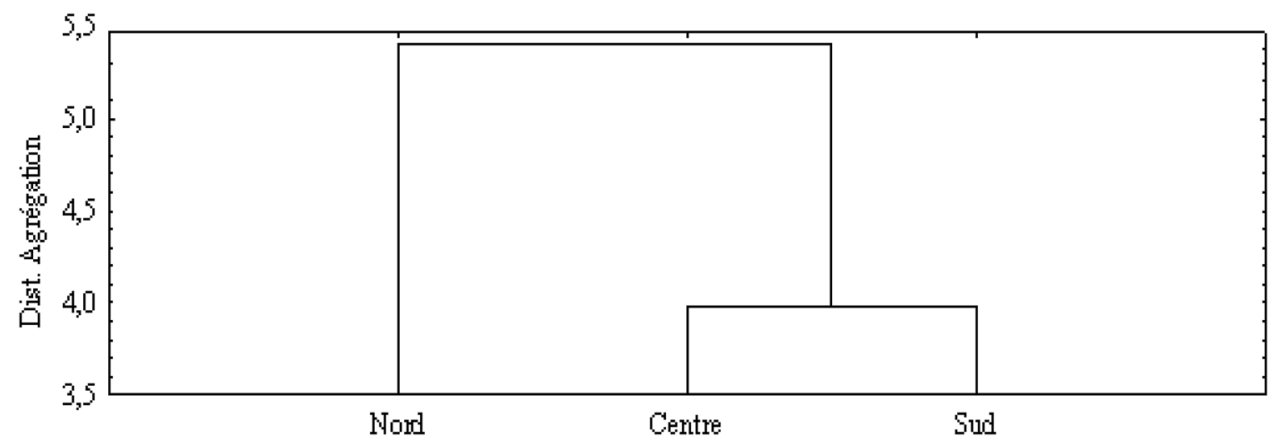

Table 3 Carob pulps' physicochemical parameters of the three studied locations

\begin{tabular}{|c|c|c|c|c|c|c|c|c|c|}
\hline & $\begin{array}{l}\text { Humidity } \\
\text { in } \%\end{array}$ & Ash in \% & $\begin{array}{l}\text { Total nitro- } \\
\text { gen in \% }\end{array}$ & $\begin{array}{l}\text { Total pro- } \\
\text { teins \% }\end{array}$ & Fats in $\%$ & $\begin{array}{l}\text { Total sugars in } \\
\mathrm{mg} / \mathrm{g}\end{array}$ & $\begin{array}{l}\text { Total phe- } \\
\text { nols in } \mathrm{mg} / \mathrm{g}\end{array}$ & $\begin{array}{l}\text { Total fla- } \\
\text { vonoids in } \\
\mathrm{mg} / \mathrm{g}\end{array}$ & Saponins \\
\hline North & $13.28 \pm 1.85^{x}$ & $3.79 \pm 0.71^{x}$ & $0.53 \pm 0.12^{x}$ & $3.35 \pm 0.79^{x}$ & $0.58 \pm 0.4^{x}$ & $416.16 \pm 130.53^{x}$ & $8.07 \pm 5.95^{x}$ & $0.17 \pm 0.13^{x}$ & $83 \pm 37^{x}$ \\
\hline Center & $13.21 \pm 1.54^{x}$ & $3.37 \pm 0.65^{y}$ & $0.62 \pm 0.14^{x}$ & $3.88 \pm 0.93^{x}$ & $0.38 \pm 0.21^{y}$ & $324.87 \pm 116.05^{x}$ & $9.41 \pm 5.67^{x}$ & $0.32 \pm 0.13^{y}$ & $56 \pm 27^{y}$ \\
\hline Southwest & $11.5 \pm 2.64^{y}$ & $3.01 \pm 1.09^{y}$ & $0.53 \pm 0.16^{x}$ & $3.34 \pm 1.02^{x}$ & $0.5 \pm 0.21^{x}$ & $414.64 \pm 142.32^{x}$ & $7.35 \pm 3.95^{\mathrm{x}}$ & $0.6 \pm 0.26^{z}$ & $111 \pm 48^{z}$ \\
\hline
\end{tabular}

Means with the same letter(s) in the same column are not significantly different at the 0.05 level

Table 4 Physicochemical parameters of the carob seeds of the three studied locations

\begin{tabular}{|c|c|c|c|c|c|c|c|c|c|}
\hline & $\begin{array}{l}\text { Humidity } \\
\text { in } \%\end{array}$ & Ash in \% & $\begin{array}{l}\text { Total nitro- } \\
\text { gen in \% }\end{array}$ & $\begin{array}{l}\text { Total proteins } \\
\%\end{array}$ & Fats in $\%$ & $\begin{array}{l}\text { Total sugars } \\
\text { in } \mathrm{mg} / \mathrm{g}\end{array}$ & $\begin{array}{l}\text { Total phenols } \\
\text { in } \mathrm{mg} / \mathrm{g}\end{array}$ & $\begin{array}{l}\text { Total fla- } \\
\text { vonoids in } \\
\mathrm{mg} / \mathrm{g}\end{array}$ & Saponins \\
\hline North & $12.45 \pm 0.72^{\mathrm{a}}$ & $4.04 \pm 0.77^{\mathrm{a}}$ & $3.59 \pm 0.47^{\mathrm{a}}$ & $22.42 \pm 2.98^{\mathrm{a}}$ & $2.54 \pm 0.95^{\mathrm{a}}$ & $66.35 \pm 18.38^{a}$ & $0.67 \pm 0.21^{\mathrm{a}}$ & $3.25 \pm 1.57^{\mathrm{a}}$ & $96 \pm 22^{\mathrm{a}}$ \\
\hline Center & $12.7 \pm 3.42^{\mathrm{a}}$ & $4.57 \pm 0.62^{b}$ & $3.85 \pm 0.36^{b}$ & $24.08 \pm 2.28^{b}$ & $2.57 \pm 1.21^{\mathrm{a}}$ & $92.09 \pm 39.5^{b}$ & $0.86 \pm 0.38^{\mathrm{a}}$ & $2.05 \pm 1.08^{b}$ & $101 \pm 34^{\mathrm{a}}$ \\
\hline Southwest & $12.19 \pm 1.01^{\mathrm{a}}$ & $3.9 \pm 0.57^{\mathrm{a}}$ & $4.03 \pm 0.72^{b}$ & $25.2 \pm 4.51^{b}$ & $2.19 \pm 0.58^{\mathrm{a}}$ & $93.57 \pm 38.47^{b}$ & $0.74 \pm 0.52^{\mathrm{a}}$ & $2.92 \pm 1.21^{\mathrm{a}}$ & $131 \pm 44^{b}$ \\
\hline
\end{tabular}

Means with the same letter(s) in the same column are not significantly different at the 0.05 level 
Fig. 2 Discriminant factor analysis of the three studied locations based on the pulps (A) and the seeds (B) physicochemical parameters
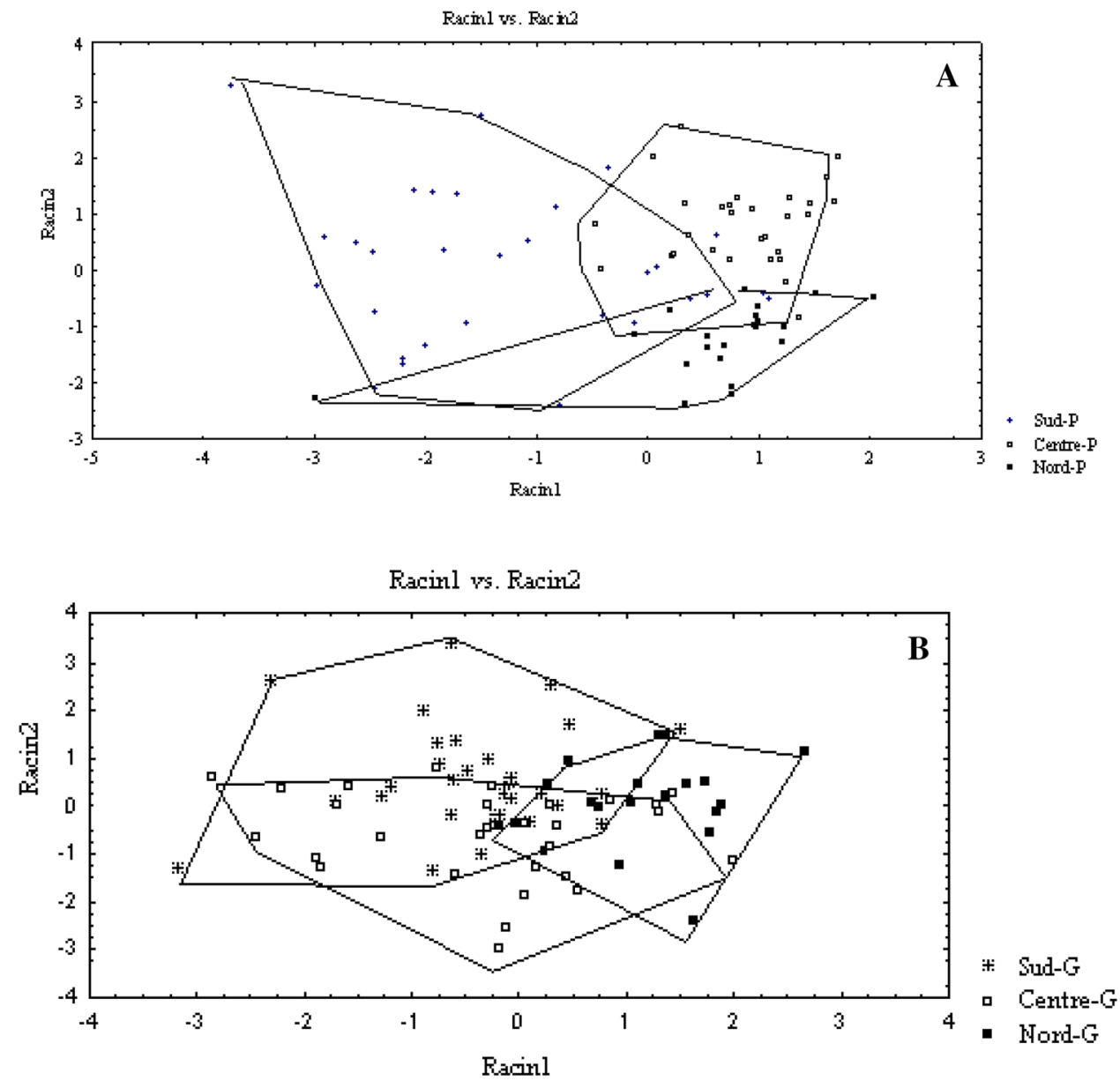

flavonoids and saponins. This is confirmed by the factorial discriminant analysis (FDA), which shows an overlap between the three studied regions (Fig. 2). Our results are in agreement with those published by Avallone et al. [23] and Yousif and Alghzawi [24] for the water content, total fat, total protein and total sugars present in the pulp of the carob tree. The values of ashes determination were in general equal to values found by Calixto and Canellas [25], Avallone et al. [23] and Yousif and Alghzawi [24]. They found an ash content ranging between 1 and $6 \%$ [23-25]. The sugar content of the pulp of the three regions of Morocco is all in agreement with the content presented by Vekiaria et al. [26]. With respect to the content of the pulp proteins in the trees from the eight localities studies, the obtained results were all in agreement with those reported by Yousif and Alghzawi [24] and Santos et al. [27]. However, these results were lower than those found by Biner et al. [28].

\section{Conclusion}

Environmental factors seem to have an important effect on the morphometric characters of pods and seeds from the carob tree investigated in this study. The environment in the northern exposure and rain appear to improve the mass, length, width and thickness of the pods compared with the other regions such as the center and southwest. They also promote the mass of seeds per pod, mass of the pulp, peduncle length, width, length and thickness of the seeds.

The increase in mass of the pulp and the seeds of the carob tree in the localities with heavy rain could increase the commercial value of the fruit of the carob tree and may increase the income of land "bours" farmers. 
The physicochemical studies showed that the pulps of the carob tree in southwestern Morocco have a higher content of flavonoids and saponins compared to the pulps of carob trees in the center and northern regions. These components have specific bioactivities, which could indicate a potential use of the southwest carob pulp in the pharmaceutical, food and medicinal plants.

The statistical analysis showed that the environmental conditions have acted the quality of carob pods. Carob trees are excellent for the population in the arid areas; indeed, these evergreen trees, widely cultivated for the edible fruit, could also be used against the desertification.

This research highlights the importance of carob tree domestication. This species does not require special cultural care and produces even during a drought year. Carob tree has a role in the sustainable development of rural people and is a real source of profit for arborists.

This kind of study rich the research on the carob trees and add novel data on this subject.

Acknowledgements The authors warmly thank Dr. Helle RAVN WEBER, Ph.D. (Silkeborg, Danemark), for the English proofreading of the manuscript.

\section{Compliance with ethical standards}

Conflict of interest All the authors declare that: this research did not receive any specific grant from funding agencies in the public, commercial, or not-for-profit sectors, they have no known competing financial interests or personal relationships that could have appeared to influence the work reported in this paper.

\section{References}

1. Bennett SJ, Maxted N (2001) Ecogeographic environment of the Mediterranean. In: Bennett SJ, Maxted N (eds) Plant genetic resources of legumes in the mediterranean. Springer, New York, pp 33-50

2. Barracosa P, Osório J, Cravador A (2007) Evaluation of fruit and seed diversity and characterization of carob (Ceratonia siliqua L.) Cultivars in Algarve region. Sci Hortic 114(4):250-257. https ://doi.org/10.1016/j.scienta.2007.06.024

3. Boublenza I, El Haitoum A, Ghezlaoui S, Mahdad M, Vasaï F, Chemat $F$ (2019) Algerian carob (Ceratonia siliqua L.) populations. Morphological and chemical variability of their fruits and seeds. Sci Hortic 256:108537. https://doi.org/10.1016/j.scien ta.2019.05.064

4. Durazzo A, Turfani V, Narducci V, Azzini E, Maiani G, Carcea M (2014) Nutritional characterisation and bioactive components of commercial carobs flours. Food Chem 153:109-113. https:// doi.org/10.1016/j.foodchem.2013.12.045

5. Dakia PA (2011) Chapter 35-Carob (Ceratonia siliqua L.) seeds, endosperm and germ composition, and application to health. In: Preedy VR, Watson RR, Patel VB (eds) Nuts and seeds in health and disease prevention. Academic Press, San Diego, pp 293-299

6. DuBois M, Gilles KA, Hamilton JK, Rebers PA, Smith F (1956) Colorimetric method for determination of sugars and related substances. Anal Chem 28(3):350-356. https://doi.org/10.1021/ ac60111a017

7. Dai GH, Andary C, Cosson-Mondolot L, Boubals D Polyphenols and resistance of grapevines to downy mildew. In, 1994. International society for horticultural science (ISHS), Leuven, Belgium, 763-766. https://doi.org/10.17660/ActaHortic.1994.381.110

8. NF-V18-101 (Octobre 1977) Aliments des animaux: Dosage des cendres brutes. Code de la norme Marocaine: NM 08.1.619(2014). Normes relatives aux commissions de normalisation instituees au niveau de l'ONSSA

9. Shang YF, Xu JL, Lee WJ, Um BH (2017) Antioxidative polyphenolics obtained from spent coffee grounds by pressurized liquid extraction. South Afr J Bot 109:75-80. https://doi.org/10.1016/j. sajb.2016.12.011

10. El Hariri B, Sallé G, Andary C (1991) Involvement of flavonoids in the resistance of two poplar cultivars to mistletoe (Viscum album L.). Protoplasma 162(1):20-26. https://doi.org/10.1007/ BF01403897

11. Singleton VL, Orthofer R, Lamuela-Raventós RM (1999) [14] Analysis of total phenols and other oxidation substrates and antioxidants by means of folin-ciocalteu reagent. Methods Enzymol 299:152-178. https://doi.org/10.1016/S0076-6879(99)99017-1

12. Makrem A, Najeh BF, Laarbi KM, Mohamed B (2006) Genetic diversity in Tunisian Ceratonia siliqua L. (Caesalpinioideae) natural populations. Genet Resour Crop Evolut 53(7):1501. https:// doi.org/10.1007/s10722-005-7761-5

13. Elfazazi K, Jbilou M, Assaidi A, Benbati M, Harrak H (2017) Morphological and biochemical variability of Moroccan carob (Ceratonia siliqua L.) produced in Beni Mellal region. Int J Pure App Biosci 5(4):14-21

14. Sidina MM, El Hansali M, Wahid N, Ouatmane A, Boulli A, Haddioui A (2009) Fruit and seed diversity of domesticated carob (Ceratonia siliqua L.) in Morocco. Sci Hortic 123(1):110-116. https ://doi.org/10.1016/j.scienta.2009.07.009

15. Goulas V, Stylos E, Chatziathanasiadou MV, Mavromoustakos T, Tzakos AG (2016) Functional components of carob fruit: linking the chemical and biological space. Int J Mole Sci 17(11):1875

16. Benchikh Y, Louaileche H, George B, Merlin A (2014) Changes in bioactive phytochemical content and in vitro antioxidant activity of carob (Ceratonia siliqua L.) as influenced by fruit ripening. Ind Crops Prod 60:298-303. https://doi.org/10.1016/j.indcr op.2014.05.048

17. Ruiz RG, Price KR, Rose ME, Arthur AE, Petterson DS, Fenwick R (1995) The effect of cultivar and environment on saponin content of Australian sweet lupin seed. J Sci Food Agric 69(3):347351. https://doi.org/10.1002/jsfa.2740690311

18. Davis JM, Murphy EA, Carmichael MD (2009) Effects of the dietary flavonoid quercetin upon performance and health. Curr Sports Med Rep 8(4):206-213. https://doi.org/10.1249/ JSR.0b013e3181ae8959

19. Hertog ML, Hollman PH (1996) Potential health effects of the dietary flavonol quercetin. Eur J Clin Nutr 50(2):63-71

20. Middleton JMDE (1996) Biological properties of plant flavonoids: an overview. Int J Pharmacogn 34(5):344-348. https:// doi.org/10.1076/phbi.34.5.344.13245

21. Mora A, Payá M, Ríos JL, Alcaraz MJ (1990) Structure-activity relationships of polymethoxyflavones and other flavonoids as inhibitors of non-enzymic lipid peroxidation. Biochem Pharmacol 40(4):793-797. https://doi.org/10.1016/0006-2952(90)90317 $-\mathrm{E}$

22. Nassourou MA, Njintang YN, Noubissié TJB, Nguimbou RM, Bell JM (2016) Genetics of seed flavonoid content and antioxidant activity in cowpea (Vigna unguiculata L. Walp.). Crop J 4(5):391397. https://doi.org/10.1016/j.cj.2016.05.011

23. Avallone R, Plessi M, Baraldi M, Monzani A (1997) Determination of chemical composition of carob (Ceratonia siliqua): protein, 
fat, carbohydrates, and tannins. J Food Compos Anal 10(2):166172. https://doi.org/10.1006/jfca.1997.0528

24. Yousif AK, Alghzawi HM (2000) Processing and characterization of carob powder. Food Chem 69(3):283-287. https://doi. org/10.1016/S0308-8146(99)00265-4

25. Calixto FS, Cañellas J (1982) Components of nutritional interest in carob pods (Ceratonia siliqua). J Sci Food Agric 33(12):13191323. https://doi.org/10.1002/jsfa.2740331219

26. Vekiari A, Ouzounidou G, Gork G, Ozturk M, Asfi M (2012) Compositional changes of major chemical compounds in Greek carob pods during development. Bull Chem Soc Ethiop 26(3):343-351

27. Santos M, Rodrigues A, Teixeira JA (2005) Production of dextran and fructose from carob pod extract and cheese whey by Leuconostoc mesenteroides NRRL B512(f). Biochem Eng J 25(1):1-6. https://doi.org/10.1016/j.bej.2005.01.022

28. Biner B, Gubbuk H, Karhan M, Aksu M, Pekmezci M (2007) Sugar profiles of the pods of cultivated and wild types of carob bean (Ceratonia siliqua L.) in Turkey. Food Chem 100(4):1453-1455. https://doi.org/10.1016/j.foodchem.2005.11.037

Publisher's Note Springer Nature remains neutral with regard to jurisdictional claims in published maps and institutional affiliations. 